\title{
5 Trouble in paradise?
}

\author{
Icelandic gender-equality \\ imaginaries, national \\ rebranding and international \\ reification
}

\section{Irma Erlingsdóttir}

The period 1970-2020 can be characterized in terms of a slow process of tearing down gendered power structures in Icelandic political and economic life. In the 1970s and 1980s, women's movements spurred critical debates about gender inequalities, which were instrumental in putting women's rights on the political agenda. Feminist activism led to the first women's strike in 1975, during which women left their jobs or homes for a day to demonstrate the importance of their contribution to society. Another important event was the 1980 election of Vigdís Finnbogadóttir as the world's first democratically directly elected female head of state. And 1983 witnessed the electoral breakthrough of a women's only movement - the Women's Alliance - which was represented in the Icelandic parliament until 1999. In all these cases, demands for the empowerment of women deeply influenced Icelandic society and the male-dominated political parties.

These achievements, however, were followed by an anti-feminist backlash in Iceland during the first decade of the twenty-first century. What has been dubbed the 'era of masculinities' coincided with a neoliberal turn driven by a group of businessmen with the active support of the political elite (Porvaldsdóttir, 2014: 52; see also Enloe, 2013; Loftsdóttir, 2015b). This led to the adoption of privatization and deregulatory policies and an unprecedented foreign expansion of Icelandic banks and private enterprises. The masculinized boom-era culture that accompanied this business-government collusion was, of course, part of a global trend. However, its effects in Iceland were especially strong and manifested themselves in essentialist and misogynist attitudes and practices. It was a classic case of the persistence of 'hegemonic masculinity' - the attempt to legitimize, normalize and reinvent patriarchy and the subordination of women (Connell, 1998; Enloe, 2017). Women were, for instance, increasingly relegated to the 'feminine sphere' by excluding them from power positions on the grounds that they were not 'risk-takers' and were too cautious by nature (see, for example, Johnson, 2018: 49).

As a result, the feminist movement in Iceland was forced on the defensive and became less influential within political structures than it had been in previous decades. The dominant political culture was guided by neoliberal

DOI: $10.4324 / 9781003017134-5$ 
and individualistic ideas about the irrelevance of gender as a political and social category. It was not until the end of 2008 - during the height of the global financial crisis, when Iceland experienced the biggest banking collapse that a country has ever suffered relative to the size of its economy that this trend was reversed. The ensuing political and economic instability did not just challenge a masculine culture of impunity; it also created the conditions for the revival of a women's agenda in the politics and economy of Iceland based on feminist critiques of the hegemonic masculine model.

Since then, gender equality has been a central focus of Icelandic government policies, playing a major role in domestic reconstruction efforts and nation-branding abroad. What the financial crisis did was to reopen a space for women in terms of political representation and participation. On an individual and symbolic level, it began, in 2009, with the formation of a left-wing government and the appointment of Jóhanna Sigurðardóttir as Iceland's first female prime minister - and the world's first gay person to hold such a position - and continued with the appointment of Katrín Jakobsdóttir as Europe's youngest female prime minister in 2017. Finally, from 2009 to 2020, driven by the women's movement and feminist members of parliament, successive coalition governments, spanning the entire political spectrum, have enacted gender-equality laws with the aim of increasing the number of women on company boards, making equal-pay certification obligatory, extending parental leave from nine months to a whole year, and expanding abortion and transgender rights (see Prime Minister's Office, Iceland, 2019).

Nation brands have a high policy value because they create and relate to images and reputations that are deeply anchored in the minds of consumers and audiences (Viktorin et al., 2018: 3). Iceland's effort to put into effect a strong gender-equality model has been a key factor in reversing its negative image after the financial collapse - together with other important factors, such as the quick economic recovery, the defiance of powerful foreign financial and political interests, especially in Britain and the Netherlands, and the decision to bring those responsible for the financial crisis to justice. Indeed, Iceland has topped the list of the World Economic Forum's Global Gender Gap Index every year since 2009. According to the World Economic Forum's 2020 survey, Iceland has closed almost $90 \%$ of the overall 'achievement gap' between women and men in four key areas: health and survival, political empowerment, economic participation and opportunity, and educational attainment (see World Economic Forum, 2020).

In this chapter, I focus on the role of Icelandic gender-equality images in national identity projections and foreign imaginaries following the 2008 financial crash. I show that there has been a fundamental change in the gendered branding of Iceland, which is directly tied to post-crisis reconstruction discourses and practices. Before the banking collapse, Icelandic image constructions, as well as foreign perceptions of them, were in many ways characterized by gendered and sexualized representations. The master 
narrative described modern-day Viking conquerors who took the world by storm on the basis of a unique Icelandic business model, combining quick decision-making and risk-taking with the maximum flexibility of a small state. In addition, Iceland was projected as a place where a vibrant urban nightlife and female promiscuity were juxtaposed with stereotypical exotic landscapes and purity of nature (Huijbens et al., 2012).

Following the financial crisis, however, the narrative shifted rapidly from masculine reification and female objectification to that of highlighting the level of gender equality in Iceland. Rooted in earlier feminist struggles of the 1970s and 1980s, this rebranding was largely made possible by activists who used the opportunity to advance a societal critique that paved the way for the adoption of concrete gender-equality policies as a crisis-response mechanism (see Enloe, 2013: 77). Their success in promoting this progressive programme was aided by a widespread belief that there was a need to escape a stigma - an image centring on a nation willing to sacrifice itself to the highest bidder during the boom era. This feminist agenda has not only been made part of official image campaigns - and inserted into the vocabulary of advertising agencies, even if they are still under neoliberal influences - but has also been incorporated into public policy and foreign policy discourses.

\section{Sexualized imaginaries of the nation}

As Viktorin et al. (2018: 2) have pointed out, nation-branding 'seeks to enhance international credibility, draw foreign investment, create international political influence, charm tourists, intensify nation building, attract and retain talent and, often, change negative connotations'. Since the nineteenth century, gender has been an important tool in such branding. In their chapter in this volume, Katarzyna Jezierska and Ann Towns (2021) argue that a number of states, including Iceland, have relied on 'androcentric and sexually objectifying representations' in the promotion of their countries. In contrast, they argue, Sweden has avoided such gendered image-making. Before the financial crash, such a portrayal was, indeed, applicable to Iceland. In the 1990s and the 2000s, when it came to nation-branding abroad, the emphasis of private companies was not only on Iceland's natural beauty but also on the people who lived there. As part of that strategy, Reykjavík was introduced as a 'global party capital'.

To underpin highly gendered marketing campaigns, there were references to beautiful Icelandic women, including two Miss World titleholders, which fit into a broader picture of alluring and healthy Nordic women with sexually liberal attitudes (Porvaldsdóttir, 2011: 421). In the early 2000s, tourist promotional strategies reinforced the stereotypical image of Icelandic women as being promiscuous. It culminated in a highly controversial Icelandair advertising campaign in London under the heading 'Fancy a Dirty Weekend in Iceland?' - which included phrases like 'Miss Iceland Awaits', 
'One Night Stand in Reykjavík' and 'Free Dip in Every Trip'. This sexualization of the public square was underlined by the sudden increase of sex clubs in Iceland, which started in the mid-1990s, reaching a peak in 2000 when 12 such clubs were operating in Iceland, mostly in the capital area (Porvaldsdóttir, 2011: 424). Much of this nascent industry was based on trafficking in women from various countries, which drove Icelandic feminists to agitate, successfully, for the shutting down of these clubs in the years following the 2009 crisis. Originally, the target group was young men, who made up the majority of tourists visiting Iceland and who were to be tempted by a wild nightlife. This worked so well that in 2005 Reykjavík nightlife was cited by tourists as one of the five major reasons for visiting Iceland; it scored higher than nature walks, horseback-riding or whale-watching (see Icelandic Tourist Board, 2005). In other words, those in charge of marketing for Icelandic tourist companies decided that Icelandic women were to be specifically targeted, in a predatory way, as 'exotically white' sexual objects. While this trend of the hypersexualization of Icelandic women was severely criticized by Icelandic women's groups, it did not exist in a cultural vacuum; it was very much a part of the persistence of patriarchal norms in a society that nonetheless prided itself on upholding women's rights (Porvaldsdóttir, 2001). It demonstrated the paradox of women being objectified in a nation internationally recognized for a high degree of gender equality (Huijbens et al., 2012: 19-32).

This image-construction coincided with the backlash against feminist politics and policies in Iceland during the highly masculinized boom era mentioned above. It reflected a set of values that were closely associated with the influence of neoliberal ideology. Clichés about modern-day Viking territorial conquerors became household metaphors for the foreign investment drive preceding the banking collapse. Such metaphors were promoted by Icelandic businessmen and parroted by the political elite and the media (see, for example, Grímsson, 2005). One can argue that the original meaning of the word 'brand' as an attempt to mark ownership captures the essence of this exercise of patriarchal power. A brand was, after all, a piece of charred or burning wood, or a hot iron mark, that farmers used to identify their stock (see Viktorin et al., 2018: 5).

As Nigel Morgan and Annette Pritchard (1998: 217-219) have stressed, tourism is intimately related to broader societal structures - whether historical, economic, political, cultural or social. Within the Icelandic context, the image of the 'sluttish supermodel' was used to describe the status of women. Indeed, even though the branding was clearly excessive in its objectification of women and was not based on the actual position of women in Iceland, it was allowed and sustained by a degree of patriarchal attitudes in Icelandic culture. Those who created such images were, of course, products of a society that perpetuated them. As part of a nation-branding strategy, they thus sought to control and channel information and to manipulate the resulting imagery (Viktorin et al., 2018: 3). 


\section{The resurrection of the women's movement after the financial crisis}

The challenges the feminist movement faced as a result of the neoliberal turn were enormous. A group of about 30 businessmen accumulated enormous economic power, enabling them to stage what has been compared to a societal 'takeover'. These 'oligarchs' became the primary donors to political candidates and parties, bought private media companies, and made sponsorship deals with public/private education and cultural institutions (Ingimundarson, 2010). The political elite aided and abetted this process. Finance Minister and later Prime Minister Geir Haarde put it this way in 2005:

few things are more rewarding in politics than to see when a good idea becomes embedded and wins in the ideological struggle.... I am sure that no one wants to return to the time when the financial sector was subjected to political control. ${ }^{1}$

The result was the weakening of state institutions, including those that were supposed to oversee the banks.

As Cynthia Enloe (2013: 76) has pointed out, the masculinized practices that led to the banking crash suggest that, for all its success, the Icelandic feminist movement in the 1990s had not yet transformed the patriarchal internal cultures of political parties' leaderships and the country's banking establishment. Hence, it should not have come as a surprise that feminists in Iceland feared another gender backlash after the economic crisis deepened (Ólafsdóttir, 2009). They reacted by setting up what they termed a women's emergency forum in October 2008. This was an informal feminist platform, established initially as a Facebook group, whose goal was to approach the crisis through a gender lens and monitor the government response to the crisis. It was politically active for several months and highly visible in the protest movement that included broad sections of society, shaking Iceland. The international media reported regularly on the Emergency Forum, which probably influenced news stories about women taking over the political sphere. The group, however, became less visible a few months later when, in the spring of 2009, the left-wing government of Jóhanna Sigurðardóttir was formed and the group's agenda was largely taken up by the government.

The shift to the left meant that the government adopted a strategy of redistribution - with the rather surprising blessing of the International Monetary Fund (IMF), which had challenged the austerity course adopted by many other governments. Facing a massive post-crisis deficit, the Sigurðardóttir government resorted to spending cuts in healthcare and education, which hit women harder than men, especially the decision to shorten the period of paid parental leave. To cushion the blow, however, it increased welfare revenues - including unemployment benefits, housing subsidies and 
pension guarantees-for lower-income groups and reduced benefits for higherincome earners. Activation and job-creation programmes were greatly stepped up and proved very important in combatting unemployment. The tax burden of the lowest earning $60 \%$ of households was reduced (Ólafsson, 2019).

The Icelandic response to the financial crisis has gained much international attention and praise, if for different and opposing reasons. Elite international institutions, such as the IMF, came early to the conclusion that Iceland's recovery programme was a major success in economic terms and were quick to take credit for its implementation. Conversely, antiestablishment grassroots movements in Europe, such as Podemos in Spain or ATTAC in France, viewed the Icelandic political experience as a form of 'people power' as manifested in the determination to oppose the power of far stronger states and financial interests, the adoption of socially responsible policies and the decision to involve the public in writing a new constitution (Ingimundarson et al., 2016).

Iceland may have been able to stage a more successful economic comeback than most of the other European countries that were particularly badly hit, such as Greece and Portugal. What shows the societal impact of the crisis is that Iceland's surprisingly speedy economic recovery - which resulted in high growth rates, full employment and debt levels that were far lower than before the banking collapse - failed to transform, politically, into a 'new normal'. Instead, highly contested political narratives about the causes and nature of the crash or about the assignment of responsibility have emerged (Ingimundarson, 2016). Yet no backlash against women's rights has occurred, even though the number of female members of parliament dropped in the 2017 elections. On the contrary, different governments have backed gender-equality policies and used Iceland's place on the World Economic Forum's Gender Gap Index to promote Iceland on the international scene, heralding a new slant to the international branding of Iceland as a paradise of gender equality.

The spotlight, as noted earlier, has also been on the role of women in Icelandic reconstruction efforts. Under the leadership of Jóhanna Sigurðardóttir, it was claimed, women were 'cleaning up the mess' left by Icelandic men. ${ }^{2}$ Internationally, much was made of the fact that two of the three new bank directors tasked with the resurrection of the Icelandic banks were women. As it was put in one exaggerated media account: 'Women took over the country and fixed it, that's what happened' (Carlin, 2012). Similarly, when a young female TV reporter, bóra Arnórsdóttir, decided while heavily pregnant, in 2012, to run for president against the incumbent, Ólafur Ragnar Grímsson - who had been intimately tied to banking expansion but managed to cut his losses by taking sides with protesters against a deal with foreign state creditors - it was portrayed as yet another sign of women's power in Iceland and representative of its gender-equality model. To be sure, Arnórsdóttir's pregnancy generated a slew of both laudatory and sceptical reactions. On 
the one hand, it was argued that her condition showed that Iceland was in a class of its own when it came to women's rights; on the other, many questioned the young mother's 'ability' to serve as leader of a nation while simultaneously fulfilling her role as a mother. ${ }^{3}$ But, in general, her presidential run received much international coverage. After the election results were announced, her defeat was in some countries, such as France, considered more newsworthy than the victory of Ólafur Ragnar Grímsson. Indeed, one could detect a certain media disappointment. ${ }^{4}$ It reflected a typical journalistic interest in 'positive' accounts of 'female accomplishments' - suggesting that gender equality is possible. This news reporting also showed how ready and willing the international media were to participate in such fantastical constructions of gender equality in Iceland, even turning a blind eye to the fact that Icelandic opinion polls had suggested well before election day that Grímsson would win with a decisive margin.

\section{The hour of the woman: gendered national rebranding}

A major change occurred in the projection of Iceland abroad after the crash, which flew to the other extreme of the sexualized gendering that had characterized the first decade of the twenty-first century. In line with the agenda of the left-wing government, which came to power in 2009, tourism promoters in Iceland began to emphasize the country's achievements and international reputation in the field of gender equality, thereby undermining the hegemonic patriarchal discourses that sustained the paradox of image versus reality. Even while the marketing of Iceland continued to focus on nature and social recreations, such as glacier trips, whale-watching, and hot springs and natural swimming pools (notably the Blue Lagoon, a major tourist attraction), far less emphasis was put on Reykjavík nightlife, although the city was still often portrayed as being 'cool' and cosmopolitan. Overtly sexualized imagery disappeared from advertising campaigns.

In the period since the crisis erupted, one can see greater similarities between the Icelandic and the Swedish cases when viewed from the perspective of official and non-official branding efforts. There are no longer systematic efforts to market Iceland as a tourist destination on the basis of what has been termed 'gendered stereotypes in which Icelandic women are portrayed as sexually available and closely connected to Icelandic nature' (Loftsdóttir, 2015a: 255). Kristín Loftsdóttir sees some continuity in the 2010 promotion campaign 'Inspired by Iceland', which relied on an extensive collaboration between the government of Iceland, the City of Reykjavík and tourist companies. ${ }^{5}$ She argues that its use of the exotic could be read as an engagement with prior representations of Icelandic women as symbolizing untouched ('wild') nature waiting to be touched and explored. However, the 2010 campaign was, in many ways, gender-sensitive and bears no real resemblance to the previous campaigns. 
'Inspired by Iceland' was launched shortly after the banking collapse, when there was a tremendous need for strong female role models. After a 2010 volcanic eruption in Iceland made global headlines and resulted in stranded passengers around the world, the decision was taken to market Iceland as a safe and secure place, with beautiful, unspoiled nature, good food and world-class artists. This approach proved to be a major success, resulting in a sharp increase in the number of tourists visiting Iceland in the following years. The pressure for a women-friendly image projection was not only reflected in grassroots activism but also felt at the official level. The left-wing government took active steps to make women's rights a core part of its foreign policy and its branding of Iceland abroad. Thus, while Iceland's relative success in relation to gender equality during the 1980s and 1990s was not used to draw tourists to Iceland, this has changed in the last decade. Many tourists visit Iceland precisely because of its image as a socially progressive country, where security and well-being are seen as part of gender equality. It is this redrawn image that has been seized, appropriated and transmitted by the global media in its coverage of Iceland as an idealized haven of gender equality.

Iceland is commonly placed somewhere in the mythical or poetical North where the impossible is possible - where gender equality is a fact but at the same time a kind of chimera, as it is often confined to an imaginary space. The argument can be made that Icelandic women are now seen as being strong indeed, so powerful that that they are almost fantastical. The image is now differently gendered: Icelandic women are still figured as extraordinary, but their power has more to do with public influence rather than with beauty or sexuality, as had been the case in the past. Such gender constructions of women can also be seen within the context of the gender-equality imaginaries of other Nordic countries. A contemporary case in point is the international media reporting of women leading the way in response to the first wave of the COVID-19 pandemic. The seven countries that were seen as offering the most effective policies were led by women. They included four Nordic countries: Iceland, Finland, Denmark and Norway (see Wittenberg-Cox, 2020).

Yet the Icelandic paradox of image versus reality persists. While, like the other Nordic countries, Iceland has been portrayed abroad in inspirational terms when it comes to gender equality, there has been a suppression of the darker side of Icelandic gender realities and of obstacles facing women. One can also trace this trend to the coverage of the Icelandic financial crisis. In the article 'The Death of Macho', published in the journal Foreign Policy in 2009, Reihan Salam went as far as to announce the demise of masculine rule. Citing Iceland as a case in point, he maintained that voters 'threw out' the all-male elite responsible for the financial catastrophe and 'named' the lesbian Jóhanna Sigurðardóttir as their prime minister. In my critique of this article, I noted that, although inspiring, this account of a gender revolution in Iceland was idealized and premature. This was not to minimize the fact 
that the crisis exposed the bankruptcy of 'macho rule' or that a handful of Icelandic women replaced men in real power positions, but rather to point out that the male elite had not been destroyed. In 2018, when the ten-year anniversary of the crash was remembered in Iceland, the 'old boys' network was still alive and clinging to power. Its continued presence was shown by the fall of two Icelandic governments - one over the Panama Papers scandal and the other over accusations of a political cover-up in connection with the government handling of a child abuse case - in 2016 and 2017, respectively.

As I have stressed here, there has been a clear shift towards gender equality in Icelandic national branding, which is sponsored officially by Promote Iceland, the official tourist board, in cooperation with private companies. Such branding has moved away from the sexualized female object to the image of a powerful woman leader. Being 'first' in some capacity is a major part of this portrayal - whether as the first elected women president, the first lesbian prime minister or the youngest female prime minister (see also Jezierska and Towns, this volume; Larsen, this volume). On the other hand, it is rarely made explicit that all these leaders came to power following a major crisis, as was the case with Prime Minster Jóhanna Sigurðardóttir, who had to deal with the biggest financial crisis since the founding of the Icelandic Republic in 1944, and with Prime Minister Katrín Jakobsdóttir, who took office in December 2017 after the collapse of the third male-led centreright government that lost the confidence of the Icelandic population before serving out its full term. Regardless of the fact that these women came to power under disturbed circumstances, their role as leaders strengthens the image of women in power, successfully lending itself to this form of nationbranding, as both male and female politicians have realized.

\section{Creating the 'equal rights paradise'}

The relationship between Iceland's positive branding of itself and the international media's affirmation and creation of this brand is significant because such image-making seeks to stimulate a desire to own the 'product' by way of consumption (Viktorin et al., 2018). Iceland's reputation has capitalized on a broader representation of the classic Nordic societal model, in which a market economy is combined with a strong welfare state based on gender equality. Nordic governments, which work closely together in international organizations, have been eager to maintain and promote this profile. For decades, the Nordic Council of Ministers has projected the image of 'world leadership in gender equality'. ${ }^{6}$ Celebratory news stories ${ }^{7}$ about Iceland's top ranking on the World Economic Forum's index for 11 consecutive years have given the impression that gender-equality processes are linear and straightforward and that they can be easily be measured. Yet the index is more about gender gaps than about levels of gender equality (see Rúdólfsdóttir, 2014). The desire to 'own' a product through consumption, however, has kept the image of Iceland as a paragon of gender equality alive and unblemished. Thus, Iceland is considered to have the smallest gender 
gap, which has sometimes been erroneously interpreted as meaning that it has achieved full equality.

Apart from female government and parliamentary participation, a key World Economic Forum index measures the number of years women have exerted political power by focusing on their ratio in government and parliament. Also taken into special consideration is the number of years, in the past half a century, that women have served as heads of state. Since Vigdís Finnbogadóttir served four consecutive four-year terms as the president of Iceland - from 1980 to 1996 - this partly explains Iceland's high score on the list - together with Jóhanna Sigurðardóttir's term as prime minister from 2009 to 2013 and that of the current prime minister, Katrín Jakobsdóttir, who has been in office since 2017. Moreover, the measurement scale on which the World Economic Forum survey is based also uses simple explanatory variables that do not show the whole picture. They do not, notably, include weak points, such as the persistent degree of gender segregation in the labour market, violence against women, or the uneven sharing of responsibilities for the upbringing of children or the care of the elderly. These factors are overlooked despite the fact that they have a great impact on gender equality in the labour market and women's chances of gaining more economic or political power. ${ }^{8}$ While Icelandic feminists have consistently sought to correct such misconceptions, foreign media reports tend to gloss over the persistence of domestic violence and gender pay gaps in Iceland. ${ }^{9}$

Awareness of these inequalities, however, should not deflect from acknowledging the enormous efforts made by Icelandic feminists in the last decade to use a more progressive political climate to push through greater gender-equality measures. Historically influenced by several factors such as equality laws in other Nordic countries, international agreements and, more recently, European Union/European Economic Area legislation, Icelandic gender-equality legislation is now being given a wider social role as part of an intersectionalist approach. Its agenda has widened to include groups such as the LGBTQI+ community, which has led to the introduction of affirmative-action programmes and legislative measures mandating the public sector to fight gender inequality and discrimination. ${ }^{10}$ The status of non-state actors, including enterprises and NGOs, such as the National Queer Association of Iceland, has also been strengthened by law and government contracts in recent years. ${ }^{11}$ Earlier, the prevailing opinion was that women were to seek education and establish themselves in the lower strata of society and work upwards from there to positions of greater influence and power. This opinion was consistent with liberal ideas that were predominant in other Nordic countries in general. It echoed the traditional liberal ideology based on the presumption that giving women equal legal rights was sufficient for the position of women vis-à-vis men to improve in due course until full equality would be reached.

While in the other Nordic countries there has been a steady rise in women's representation, in Iceland changes only seem to occur when there is a major systemic challenge in politics or the economy. Icelandic political 
scientist Auður Styrkársdóttir (2012) has aptly compared waves of women's democratic enfranchisements throughout the twentieth century with natural upheavals, such as earthquakes or volcanoes (see also Erlingsdóttir, 2011). The financial crisis proved to be one such seminal moment. In the 2009 parliamentary elections, the number of women members of parliament rose from $32 \%$ to $43 \%$. These results were also reflected in municipal elections the following year, where the levels of women reached $40 \%$. Never before had women been better represented at the national and local levels in Icelandic politics. When the left-wing government was formed in 2009 , gender parity was achieved for the first time, with women holding an equal number of government posts as men. Many saw this as a culmination of feminist activism dating back to the 1980s, when the Women's Alliance played an instrumental role in boosting women's representation in parliament and other political institutions.

The increased participation of women in Icelandic politics has, historically, been based on the women's movement for equal rights and representation. This movement was evident in the 2009 government, which identified itself with feminist ideology, highlighting equality and women's liberation in its manifesto. ${ }^{12}$ Soon after assuming power, it pushed several laws through parliament that had been on the agenda of the Icelandic women's movement. The changes included making paying for sex illegal as in the Swedish model, banning strip clubs - making Iceland the first country to do so on gender grounds rather than religious ones - and imposing a gender quota system on the boards of both private and state-owned major companies. The government also initiated work on an Equal Pay Standard, which was published in 2012 and served as a basis for a 2018 law on equal-pay certification. This law made Iceland the first country in the world to require companies with 25 or more employees to obtain official certification to prove they offer equal pay for work of equal value regardless of gender. ${ }^{13}$ The same year, legislation on the equal treatment of individuals irrespective of race, ethnic origin, religion, life stance, disability, reduced working capacity, age, sexual orientation, gender identity, sexual characteristics or gender expression was passed.

Interestingly, the policies adopted in 2009 have been expanded by successive governments, which have included right-wing parties with a history of opposing affirmative-action programmes. While the left has historically been responsible for developing such policies, all the established parties, including the moderate right, have taken part in implementing them. To be sure, some conservative and populist political forces have been far less supportive of policies such as the liberalization of abortion rights, but there has been no backlash over them. This shows that there is a cross-political consensus on the promotion of the gender-equality model, which, in turn, has been seen in conjunction with Iceland's post-crisis rebranding efforts. Combined with the ongoing efforts of feminist organizations in the country, the agenda of gender equality is now firmly entrenched in the political matrix. Thus, in 2019, Iceland passed legislation on trans and intersex rights 
without any public conflict (Fisher, 2019). The same year, the parliament passed a bill on abortion, repealing the previous Act on Abortion dating back to 1975. The new law codifies women's personal autonomy and selfdetermination over their own bodies and legalizes the termination of a pregnancy within the first 22 weeks regardless of circumstances. ${ }^{14}$

Finally, as an example of the influence of Icelandic feminist activism abroad, two additional developments can be mentioned: First, the women's strike in 1975 (also called 'Women's Day Off'), which brought the country to a standstill, recently served as a historical model both in Iceland and internationally. While the strike has been repeated five times in Iceland - in 1985, 2005, 2010, 2016 and 2018 - it was used as a reference point in Poland in 2016, when thousands of women went on strike in protest against proposals for a total ban on abortions. ${ }^{15}$ The initiative inspired women's and feminist organizations in Argentina, including the Ni Una Menos collective, to organize a one-hour strike and mass mobilizations that were replicated in most countries of Latin America and the Caribbean (James, 2018). This cascade inspired by the Icelandic model led to a global movement with the first International Women's Strike taking place in more than 50 countries on 8 March 2017 (Topping and Redden, 2017). Second, the Women's Alliance has been tied to political empowerment of women not only in Iceland but also in other countries (Schneier, 1992). More than 30 women's parties have been established on the national or municipal levels since 1987 (Evans and Kenny, 2019). Until the early 1980s, the participation of women in Icelandic politics had been very low, with women comprising only about $2 \%-5 \%$ of parliamentarians and being mostly excluded from traditional political parties. The Women's Alliance's entry into parliament led to major changes with respect to female political representation.

Thus, what has made Iceland so visible in the area of gender equality internationally is that it has been able to integrate the image of the Nordic welfare state with specific feminist actions in the past as part of a successful crisis response in the present. While this branding has both been intentional and unintentional, it has served to enhance the country's profile and reputation management abroad.

\section{The elevation of gender equality in Iceland's foreign policy}

Given the intense pressure facing the Icelandic government abroad in the wake of the financial crisis, it realized it had to make sustained efforts to improve its image in a field where it could show credibility. Needless to say, this led to the abandonment of the disastrous masculine nation-branding strategy - as articulated by politicians, businessmen and the media - based on the 'successes' of the Icelandic banking expansion (Prime Minister's Office, Iceland, 2008). Instead, gender equality was made a core issue in Icelandic foreign policy (Cull, 2016: 156). While it is true that gender equality had already become part of Iceland's international development cooperation in 
2007, when a feminist foreign minister, Ingibjörg Sólrún Gísladóttir, put women's empowerment on the agenda, it was not yet firmly embedded. Gísladóttir, a former member of parliament for the Women's Alliance, was at that time the leader of the Social Democratic Alliance, which formed a coalition government with the conservative Independence Party from 2007 to 2009. This government was brought down by the financial crisis. The piecemeal inclusion of gender issues in government policy by Gísladóttir was a direct legacy of the Women's Alliance. Even if the women's movements and feminist ideologies had a fundamental impact on Icelandic society in the twentieth century, they were hardly reflected in Iceland's realistoriented foreign policy based on its military ties with the United States and NATO during and after the Cold War. Iceland's international image and interaction with other nations, in other words, did not include issues of gender equality. After the crash, however, things began to change. There was a significant increase in the number of women in the foreign ministry and among ambassadors, and even the influence of the peace agenda of the Women's Alliance, which had been ignored in Iceland's foreign policy in the 1980s and 1990s, can be detected after 2009 (Ómarsdóttir, 2010).

Thus, gender equality has been prioritized in Iceland's foreign policy thanks in large part to feminists inside and outside political parties who have put pressure on the government (Ómarsdóttir, 2010). Among further measures taken was the establishment in 2009 of a United Nations Gender Equality Studies and Training Programme (GEST) - funded by the Icelandic Foreign Ministry and targeted at students from developing and postconflict countries - at the University of Iceland. ${ }^{16}$ Gender-equality expertise has often been presented as a Nordic export commodity. EU countries Sweden, Finland and Denmark have mostly focused on influencing other EU member-states, while Norway and Iceland's aim has been to promote gender equality in developing and post-conflict countries. The GEST programme ${ }^{17}$ was promoted by academics on the grounds that if Iceland was to sponsor development projects in the geothermal, fisheries and land-restoration fields - where its performance had been noted abroad - gender equality was another area where Iceland could play a role and take on international responsibility. GEST thus owes its very existence and funding to the fact that it is seen as playing up the strengths of Iceland in the field of gender equality, and it is an integral part of Iceland's development policy and peacebuilding agenda. Its mission and academic aim is to engage in a critical debate about equality, not to impose standards or policies for women's empowerment on developing countries. The driving force behind the project is a critical, even radical, feminist stance on development and international politics. This means that its content does not always harmonize with the Foreign Ministry's broader national-branding agenda or political interests, even if it reflects the goal of promoting gender equality. Yet, being at the same time part of Iceland's governmental efforts, it is sometimes challenged by official ideas about nation-branding and feminism in its neoliberal form. 
Another part of Iceland's foreign policy and gender strategy includes political and financial support for UN Women, and, recently, it has extended its agenda to addressing discriminatory stereotypes of masculinity and engaging men and boys for gender equality. Towards this effort, the Ministry for Foreign Affairs has organized so-called Barbershop discussions around the world, which are consistent with Iceland's participation in the HeForShe campaign. The Barbershop concept was developed jointly by the Permanent UN Missions of Iceland and Suriname (countries ranked best and worst in the World Economic Forum's 2013 report) within the context of the 20th anniversary of the Beijing Declaration and Platform for Action in 2015. The purpose was to bring men to the table as partners for gender equality, encouraging them to look at their own attitudes and behaviour. Several Barbershop conferences have been held, including at the UN, the Nordic Council of Ministers, NATO, the Council of Europe, the Icelandic parliament and the Icelandic Ministry for Foreign Affairs. ${ }^{18}$ While they were envisaged as a discussion platform for men, they have always been open to women (United Nations, 2015).

To be sure, the initiative has not been without criticism. According to Dyan Mazurana, who contributed to the 2002 Women, Peace and Security report for the UN Security Council, women 'don't want to be spoken for, we'd like to speak for ourselves'. She also noted that the UN 'has a long and disgraceful history of men-only meetings on issues that are foundational to the rights of women' (Tulinius, 2014). The idea was, however, welcomed by others, such as Gary Barker, who works for Promundo, a Brazilian organization that aims to enlist men in the struggle for gender equality on the grounds that it was not meant to replicate 'smoke-filled rooms' but to create a safe space for male political leaders to talk about ways to engage men in the ongoing efforts to reduce violence against women (Tulinius, 2014). The idea can, in fact, be attributed to former Icelandic President Vigdís Finnbogadóttir, who had for many years appealed for ways to include men in the gender-equality debate. The idea was subsequently developed further by feminists within the Icelandic Foreign Ministry, who wanted to experiment with it at the United Nations. Foreign Minister Gunnar Bragi Sveinsson decided to organize and campaign for the Barbershop conference there in 2015. In a disastrous instance of the paradox of gender equality existing within and alongside patriarchal behaviour, Sveinsson's mandate was tainted by his role in a political scandal with highly gendered dimensions in 2018. He was among a few male parliamentarians and one woman member of parliament caught on tape demeaning, in a highly misogynistic way, their female parliamentary colleagues. Thus, while Mazurana's criticism of male-dominated meetings was not directed at Sveinsson personally, it conveyed an eerie sense of premonition. It underlined the need for a systemic rooting out of patriarchal misogyny from society if the image and aspiration of gender equality was to become reality (Grettisson, 2018). 
On the international stage, however, Iceland continued to play its part in furthering the agenda of gender equality. Elected to the UN Human Rights Council following the withdrawal of the United States from the body in June 2018, it focused in particular on women's rights and gender equality, LGBTQI+ rights, and the rights of the child. Another initiative that fed into the international view of the equality brand was the annual Reykjavík Women Leaders Global Forum, ${ }^{19}$ which was launched in 2017 with the participation of women leaders from all over the world. It has now been organized three years in a row in Iceland with a growing number of participants. Here, far removed from its earlier branding as the dirty-weekend capital, Reykjavík has been rebranded as a platform where women leaders share ideas on how to further advance society with explicit references to Iceland's place on the World Economic Forum's Gender Gap Index and to past and present Icelandic female leaders. Former President Vigdís Finnbogdóttir is internationally praised for her part in paving the way for women's political leaders; former Prime Minister Jóhanna Sigurðardóttir played a key role in the post-crash reconstruction efforts and became globally known as the first openly lesbian prime minister when the international media got wind of her sexual orientation. In Iceland, however, her sexuality was never made an issue or considered worthy of any media exposure. In continuance of this legacy, the current prime minister, Katrín Jakobsdóttir, accepted in February 2020 the appointment to the chair of the Council of Women World Leaders, an organization established by Finnbogadóttir in 1996 (Government of Iceland, 2020a). And, in line with the government promotion of gender equality, in Iceland and abroad, the competency for this policy area was transferred from the auspices of the Ministry of Welfare to the Prime Minister's Office in January 2019. ${ }^{20}$

In spite of all its prominence in terms of gender equality on the international stage, one should not exaggerate the influence of a small country like Iceland on the gender-equality policies of other countries. However, its stature is enhanced in association with other Nordic countries with which it shares a reputation as a 'norm entrepreneur' in the field of gender equality (Ingebritsen, 2002). Iceland's credibility is also enhanced by its consistent support for gender equality since 2009, irrespective of whether governments have been led by the left or right. In this sense, as I have argued here, gender equality and state-supported feminism have become part of both a national aspiration and a national branding strategy that seems to work well for Iceland on the level of foreign policy and business.

\section{Conclusion}

While adhering to international notions of altruistic Nordic 'exceptionalism', Nordic gender-equality branding has also much to do with Realpolitik or with what Louis Clerc and Nikolas Glover (2015: 12) have termed 'the necessity for small states to act in character'. This applies to Iceland's nation-branding with respect to gender equality, which was about creating 
an image or a product to negotiate an emotional relationship between brand owners and prospective customers to repair its reputation abroad (Viktorin et al., 2018: 4). It points to the inherent tension in such politicized marketing projects - with self-interested state and corporatist practices often being conflated with idealistic motivations for social change and partnerships with civil society (Viktorin et al., 2018: 11). Since Iceland has by no means achieved gender parity, such image-making not only can adversely affect the struggle for women's rights and help 'normalize' gender discrimination but can also reinforce the notion that a state of perfection has been reached. In other words, the Icelandic gender-equality imaginary risks being appropriated and redefined by the state, which is as much concerned with elevating Iceland as a national brand driven by market motives. The lack of any critical engagements with the measurement flaws inherent in gender-gap indices or the persistence of gender inequalities in Icelandic society undermines the official message about Icelandic 'exceptionalism'.

This is not to say that nothing has been achieved. Exoticism, with its many problematic gender connotations, has continued to dominate the marketing strategies of the Icelandic tourist industry. But, in contrast to the first decade of the twenty-first century, Icelandic companies have, as I have stressed, moved away from the objectification and sexualization of women. What is more, the branding of equality made it possible to access positive memories of past feminist successes as well as to overcome the stigma associated with the Viking business expansion and its masculine-driven excesses. It is true that Icelandic policies on gender cannot be separated from what can be termed symbolic politics. Successive governments continue to issue universal proclamations on gender equality even if they pay little attention to minorities, such as immigrants, and provide inadequate financial resources to develop and finance policy decisions. Nonetheless, the Icelandic Foreign Ministry and the tourist industry have managed to capitalize on Iceland's gender-equality record in government-supported nation-branding campaigns. That this image fits with pre-existing, traditional ones of Iceland as being progressive on women's rights also explains why state representatives harp on the issue, for they know that it resonates among foreign publics (Clerc and Glover, 2015: 12). Such attitudes only confirm that strategies of nation-branding are less about mutual understanding among nations and more about image management by publicly touting positive 'national characteristics'. However, as the Icelandic experience in the past decade shows, they can also be used effectively to further an agenda of gender equality, even while rescuing the national brand of a small state that was in acute danger of permanent damage.

\section{Notes}

1 Geir H. Haarde, 'Address on the Occasion of the SBV Day', 7 April 2005, cited in Sigfúsdóttir (2011: 1).

2 See, for example, Gros (2012a); Ertel (2009); O’Connor (2008); Sunderland (2009). 
3 See BBC News (2012a, 2012b); Chocas (2012); Gros (2012b); Chabas (2012a); Jonanin (2012); McVeigh (2012); Grontoft (2012).

4 See, for example, Chabas (2012b); Gros (2012c).

5 See https://www.inspiredbyiceland.com (accessed 19 April 2020).

6 See Prime Minister's Office, Iceland (2019).

7 See, for example, Economist (2018); Hertz (2016); Pelaez (2018); Women Political Leaders (2014); BBC News (2010); Noman (2015); Johnson (2011).

8 The World Economic Forum's Gender Gap Index ranks countries according to a calculated gender gap between women and men in only four areas: health, education, economy and politics. For more detailed information about the status of gender equality in Iceland, see Icelandic Human Rights Centre and Icelandic Women's Rights Association (2016); Prime Minister's Office, Iceland (2019).

9 There are exceptions, though; see Domonoske (2018); Independent (2017).

10 The most-effective affirmative action being the comprehensive law on parental leave that came into effect in 2000 (see Arnalds et al., 2013). In June 2018, the Icelandic parliament approved a law banning, among other things, employment discrimination based on sexual orientation, gender identity, gender expression and sex characteristics. The law, known as the Law on Equal Treatment in the Workplace, took effect on 1 September 2018. In June 2019, the parliament enacted a law on the self-determination of gender change, which is consistent with similar laws adopted in numerous European and South American countries. The new law allows transgender individuals to change their legal gender without having to receive a medical and mental disorder diagnosis or undergo sterilization and sex-reassignment surgery. Minors may also change their legal gender with parental consent. Furthermore, the law allows individuals to choose a third gender option known as ' $\mathrm{X}$ ' on official documents.

11 See the Agreement between the Prime Minister's Office and the National Queer Organisation, February 2019 (Stjórnarráo Íslands, 2019a); Agreement between the Icelandic Women's Rights Association and the Prime Minister's Office, June 2019 (Stjórnarráð Íslands, 2019b).

12 See the Government Declaration of the Social Democratic Alliance and the Left Green Movement from 2009 (Stjórnarráð Íslands, 2009).

13 See Government of Iceland (2014).

14 The new legislation codifies the personal autonomy and self-determination women have over their own bodies and guarantees the right to healthcare in relation to abortion on demand up until the end of the 22nd week of pregnancy. See Fontaine (2019); International Campaign for Women's Rights to Safe Abortion (2019).

15 Gosia Wochowska of Gals4Gals Lodz stated that 'Icelandic women gave us inspiration to organize ourselves in defense of women's rights in Poland in the recent years, and therefore now we would like to offer them our support in turn'. Elena Pontil from the Italian Non Una Di Meno was also quoted as saying that "none of European countries is free from gender earnings gaps, and Iceland already has one of the lowest gender earnings gaps in the world. So we believe that this is actually a great opportunity to highlight the problem in our countries too'; see Kvenréttindafélag Íslands (2018). See also Suchanow (2020).

16 Guðlaugur Pór Pórðarson, Iceland's minister for foreign affairs, has stressed that the Gender Equality Studies and Training Programme (UNU-GEST) reflects Iceland's strong emphasis on gender equality in its international development work; see Government of Iceland (2020b).

17 On the GEST programme, see www.gest.org (accessed 19 April 2020).

18 The National Committee and the Ministry for Foreign Affairs developed a Barbershop toolbox to make the Barbershop available to all HeForShes who want 
to engage men and boys in their communities, workplaces, schools or elsewhere; see http://www.heforshe.org/en/barbershop (accessed 19 April 2020).

19 On the Reykjavik Women Leaders Global Forum, see its website at https:// reykjavikforum.global.

20 It is now the role of the Prime Minister's Office to enforce the Gender Equality and Anti-Discrimination Acts as well as to administrate the overall governmental coordination. The aim is to advance policy-making on gender equality and mainstreaming of polices and decision in all lines of ministries and state institutions.

\section{References}

Arnalds ÁA, Eydal GB and Gíslason IV (2013) Equal rights to paid parental leave and caring fathers: The case of Iceland. Icelandic Review of Politics and Administration 9(2): 323-344.

BBC News (2010) Iceland best country for gender equality. 12 October. Available at: https://www.bbc.com/news/business-11517459 (accessed 19 April 2020).

BBC News (2012a) Meet the Icelandic mother hoping to be president. 29 June. Available at: https://www.bbc.com/news/av/world-europe-18655735/meet-theicelandic-mother-hoping-to-be-president (accessed 19 April 2020).

BBC News (2012b) On the campaign trail nappies in hand. 29 June. Available at: https://www.bbc.com/news/av/world-18638878/on-the-campaign-trail-nappies-inhand (accessed 19 April 2020).

Carlin J (2012) A Nordic revolution: The heroines of Reykjavik. Independent, 21 April. Available at: https://www.independent.co.uk/news/world/europe/a-nordicrevolution-the-heroines-of-reykjavik-7658212.html (accessed 18 April 2020).

Chabas C (2012a) Journaliste vedette et jeune maman, Thora veut rendre confiance à l'Islande. Le Monde, 29 June. Available at: https://www.lemonde.fr/europe/ article/2012/06/29/journaliste-vedette-et-jeune-maman-thora-veut-rendreconfiance-a-1-islande_1727041_3214.html (accessed 19 April 2020).

Chabas C (2012b) Islande. Vingt ans de présidence pour Olafur. Le Monde, 1 July. Available at: https://www.lemonde.fr/europe/article/2012/07/01/islande-vingt-ansde-presidence-pour-olafur_1727515_3214.h (accessed 19 April 2020).

Chocas V (2012) Thora, mère d'Islande. Le Figaro, 25 June. Available at: https:// madame.lefigaro.fr/societe/thora-mere-dislande-250612-232853 (accessed 19 April 2020).

Clerc L and Glover N (2015) Representing the small states of Northern Europe: Between imagined and imaged communities. In: Clerc L, Glover N and Jordan P (eds) Histories of Public Diplomacy and Nation Branding in the Nordic and Baltic Countries: Representing the Periphery. Leiden: Brill-Nijhoff, 3-20.

Connell RW (1998) Masculinities and globalization. Men and Masculinities 1(1): $3-23$.

Cull NJ (2016) A region speaks: Nordic public diplomacy in historical context. Place Branding and Public Diplomacy 12(2-3): 152-159.

Domonoske C (2018) Companies in Iceland now required to demonstrate they pay men, women fairly. NPR, 3 January. Available at: https://www.npr.org/sections/ thetwo-way/2018/01/03/575403863/companies-in-iceland-now-required-todemonstrate-they-pay-men-women-fairly?t=1587214743795 (accessed 17 April 2010). 
Economist (2018) The best place to be a woman? 19 December. Available at: https:// www.youtube.com/watch?v=17fyqpHKARg (accessed 19 April 2020).

Enloe C (2013) Vikings and the smartest guys: Masculinities in the banking crash. In: Enloe C, Seriously! Investigating Crashes and Crises as if Women Mattered. Berkeley \& Los Angeles: University of California Press, 49-85.

Enloe C (2017) The Big Push: Exposing and Challenging the Persistence of Patriarchy. Oakland: University of California Press.

Erlingsdóttir R (2011) Kynbundin valdakerfi í stjórnmálum. Published on the resource page of the Icelandic Directorate of Equality. Available at: https://www. jafnretti.is/is/um-jafnrettisstofu/greinar/kynbundin-valdakerfi-i-stornmalum (accessed 19 April 2020).

Ertel M (2009) Cleaning up the men's mess: Iceland's women reach for power. Spiegel International, 22 April. Available at: https://www.spiegel.de/international/europe/ cleaning-up-the-men-s-mess-iceland-s-women-reach-for-power-a-620544.html (accessed 18 April 2020).

Evans E and Kenny M (2019) The Women's Equality Party: Emergence, organisation and challenges. Political Studies 67(4): 855-871.

Fisher O (2019) On trans issues, Iceland has just put Britain to shame. Guardian, 21 June. Available at: https://www.theguardian.com/commentisfree/2019/jun/21/ trans-issues-britain-iceland-law-intersex-rights (accessed 22 February 2020).

Fontaine A (2019) Iceland passes landmark abortion law. Reykjavík Grapevine, 14 May. Available at: https:/grapevine.is/news/2019/05/14/icelands-parliamentpasses-landmark-abortion-law (accessed 19 April 2020).

Government of Iceland (2014) Equal pay certification. Available at: https://www. government.is/topics/human-rights-and-equality/equal-pay-certification (accessed 14 April 2020).

Government of Iceland (2020a) Katrín Jakobsdóttir, prime minister of Iceland is chair of the Council of Women World Leaders. Available at: https:// www.government.is/ministries/prime-ministers-office/chairmanship-in-thecouncil-of-women-world-leaders/katrin-jakobsdottir-prime-minister-of-iceland (accessed 20 April 2020).

Government of Iceland (2020b) Iceland remains the top country on the World Economic Forum's Index for Gender Parity. 18 December. Available at: https://www. government.is/diplomatic-missions/embassy-article/2019/12/18/Iceland-remainsthe-top-country-on-the-World-Economic-Forums-index-for-gender-parity/ (accessed 18 April 2020).

Grettisson V (2018) The architect for the Barbershop-Conference openly misogynist. Reykjavik Grapevine, 29 November. Available at: https:/grapevine.is/ news/2018/11/29/the-architect-for-the-barbershop-conference-openly-misogynist/ ?steady_tried_to_set_safari_fix_cookie (accessed 19 April 2020).

Grímsson ÓR (2005) How to succeed in modern business: Lessons from the Icelandic voyage. Speech by the President of Iceland at the Walbrook Club, London, 3 May 2005. Available at: https://grapevine.is/mag/articles/2008/10/10/how-tosucceed-in-modern-business-olafur-ragnar-grimsson-at-the-walbrook-club/ (accessed 6 August 2020).

Grontoft K (2012) Thora Arnorsdottir (37) er nybakt mor og presidentkandidat. Aftenposten, 11 June. Available at: https://www.aftenposten.no/norge/i/awe0M/thoraarnorsdottir-37-er-nybakt-mor-og-presidentkandidat (accessed 19 April 2020). 
Gros M-J (2012a) L'Islande tout feu tout femmes. Libération, 24 April. Available at: https://www.liberation.fr/planete/2012/04/24/1-islande-tout-feu-tout-femmes 814073 (accessed 19 April 2020).

Gros M-J (2012b) Thora Arnorsdottir: Couches populaires. Libération, 14 June. Available at: https://www.liberation.fr/planete/2012/06/14/thora-arnorsdottircouches-populaires_826376 (accessed 19 April 2020).

Gros M-J (2012c) Olafur Ragnar Grimsson elu president pour la cinquème fois. Liberation, 1 July. Available at: https://www.liberation.fr/planete/2012/07/01/olafurragnar-grimsson-elu-president-pour-la-cinquieme-fois_830381 (accessed 19 April 2020).

Hertz N (2016) Why Iceland is the best place to be a woman. Guardian, 26 October. Available at: https://www.theguardian.com/lifeandstyle/2016/oct/24/iceland-bestplace-to-be-women-equal-gender-maternity (accessed 19 April 2020).

Huijbens E, Alessio D, Margaryan L and Jóhannsdóttir AL (2012) Birtingarmyndir kyngervis og pversagnir í markaðsefni íslenskrar ferðapjónustu. Íslenska pjóðfélagið 3: 19-39.

Icelandic Human Rights Centre and Icelandic Women's Rights Association (2016) Icelandic Shadow Report for CEDAW. Available at: http://kvenrettindafelag.is/ wp-content/uploads/2016/02/skuggaskyrsla_web.pdf (accessed 19 April 2020).

Icelandic Tourist Board (2005) Könnun Ferðamálaráðs Íslands meðal erlendra ferðamanna. Niðurstöður fyrir timabilið september 2004-maí 2005. Available at: https://www.ferdamalastofa.is/static/files/konn_vetur0405_vefur/index.html (accessed 19 April 2020).

Independent (2017) Gender equality leader Iceland criticized over sexual abuse statistics. 12 December. Available at: https://www.independent.ie/world-news/genderequality-leader-iceland-criticised-over-sexual-abuse-statistics-36401282.html (accessed 17 April 2020).

Ingebritsen C (2002) Norm entrepreneurs: Scandinavia's role in world politics. Cooperation and Conflict 37(1): 11-23.

Ingimundarson V (2010) A 'crisis of affluence': The politics of an economic breakdown in Iceland. Irish Studies in International Affairs 21: 57-63.

Ingimundarson V (2016) The politics of transition, memory and justice: Assigning blame for the Icelandic crisis. In: Ingimundarson V, Erlingsdóttir I and Urfalino P (eds) Iceland's Financial Crisis. London: Routledge, 140-155.

Ingimundarson V, Erlingsdóttir I and Urfalino P (2016) Introduction. In: Ingimundarson V, Erlingsdóttir I and Urfalino P (eds) Iceland's Financial Crisis. London: Routledge, 1-18.

International Campaign for Women's Rights to Safe Abortion (2019) Iceland An already liberal abortion law further reformed: 'Ready for the 21st century'. 17 May. Available at: https://www.safeabortionwomensright.org/icelandan-already-liberal-abortion-law-further-reformed-ready-for-the-21s (accessed 17 April 2020).

James S (2018) Decades after Iceland's 'day off', our women's strike is stronger than ever. Guardian, 8 March. Available at: https://www.theguardian.com/commentisfree/2018/ mar/08/iceland-global-womens-strike-protest (accessed 19 April 2020).

Jezierska K and Towns A (2021) Variations on shared themes: Branding the Nordics as gender-equal. In: Larsen E, Moss SM and Skjelsbæk I (eds) Gender Equality and Nation-Branding in the Nordic Region. Abingdon: Routledge. 
Johnson JE (2011) The most feminist place in the world. Nation, 3 February. Available at: https://www.thenation.com/article/most-feminist-place-world/ (accessed 16 February 2020).

Johnson JE (2018) The Gender of Informal Politics: Russia, Iceland and TwentyCentury Male Dominance. Basingstoke: Palgrave McMillan.

Jonanin P (2012) Journalist Thora Arnorsdottir is the favourite in the Icelandic presidential election, to be held on 30th June. Foundation Robert Schuman: The European Elections Monitor, May. Available at: https://www.robert-schuman. eu/en/eem/1313-journalist-thora-arnorsdottir-is-the-favourite-in-the-icelandicpresidential-election-to-be-held-on-30th-june (accessed 19 April 2020).

Kvenréttindafélag Íslands (2018) Iceland's women's strike on a European level. 22 October. Available at: https://kvenrettindafelag.is/2018/icelandic-womens-strikeon-a-european-level (accessed 27 July 2020).

Larsen E (2021) 'The gender-progressive Nordics': A matter of history. In: Larsen E, Moss SM and Skjelsbæk I (eds) Gender Equality and Nation-Branding in the Nordic Region. Abingdon: Routledge, 13-38.

Loftsdóttir K (2015a) The exotic North: Gender, nation branding and postcolonialism in Iceland. NORA - Nordic Journal of Feminist and Gender Research 23(4): 246-260.

Loftsdóttir K (2015b) Vikings invade present-day Iceland. In: Durrenberger EP and Pálsson G (eds) Gambling Debt: Iceland's Rise and Fall in the Global Economy. Boulder: University Press of Colorado, 3-14.

McVeigh T (2012) She's young, blonde, polite and doesn't do party politics: Just the guy for president. Guardian, 23 June. Available at: https://www.theguardian.com/ world/2012/jun/23/iceland-europe-news (accessed 19 April 2020).

Morgan N and Pritchard A (1998) 'Mood marketing' - The new destination branding strategy: A case study of 'Wales' the brand. Journal of Vacation Marketing 4(3): 215-229.

Noman N (2015) What Iceland did to become the most feminist country in the world. Mic, 13 August. Available at: https://www.mic.com/articles/114962/here-s-howiceland-became-the-most-feminist-country-in-the-world (accessed 19 April 2020).

O'Connor S (2008) Icelandic women to clean up 'male mess'. Financial Times, 13 October. Available at: https://www.ft.com/content/c347a766-994b-11dd-9d48000077 b07658 (accessed 18 April 2020).

Ólafsdóttir K (2009) Gender effects of the economic crisis. In: Hannibalsson I (ed.) Rannsóknir i félagsvísindum X. Viðskipta- og hagfraðideild. Reykjavík: Félagsvísindastofnun Háskóla Íslands, 343-352.

Ólafsson S (2019) Iceland's strategy of redistribution. In: Ólafsson S, Daly M, Kangas $\mathrm{O}$ and Palme $\mathrm{J}$ (eds) Welfare and the Great Recession: A Comparative Study. Oxford: Oxford University Press, 132-153.

Ómarsdóttir SB (2010) Áhrif femínisma á utanríkisstefnu Íslands 1999-2009. Stjórnmál og stjórnsýsla 6(1): 73-94.

Pelaez MW (2018) Is female-friendly Iceland a gender equality paradise? Globe Post, 15 February. Available at: https://theglobepost.com/2018/02/15/iceland-genderequality/ (accessed 27 July 2020).

Prime Minister's Office, Iceland (2008) Ímynd Íslands: Styrkur, staða og stefna. Reykjavík. Available at: https://www.ferdamalastofa.is/is/tolur-og-utgafur/utgefidefni/imynd-og-markadsmal/imynd-islands (accessed 16 February 2020). 
Prime Minister's Office, Iceland (2019) Iceland's Report on Beijing +25 . Available at: https://www.unece.org/fileadmin/DAM/RCM_Website/Iceland.pdf (accessed 19 April 2020).

Rúdólfsdóttir G (2014) Iceland is great for women, but it's no feminist paradise. Guardian, 28 October. Available at: https://www.theguardian.com/ commentisfree/2014/oct/28/iceland-women-feminist-paradise-gender-gap-pay (accessed 19 April 2020).

Salam R (2009) The death of macho. Foreign Policy, 21 June. Available at: https:// foreignpolicy.com/2009/06/21/the-death-of-macho (accessed 27 July 2020).

Schneier E (1992) Icelandic women at the brink of power. Scandinavian Studies 64(3): 417-438.

Sigfúsdóttir VP (2011) Réttarstaða ráðherra sem sakborninga fyrir Landsómi í ljósi stjórnarskrár lýðveldisins Íslands og Mannréttindasáttmála Evrópu. ML thesis in law, University of Bifröst.

Styrkársdóttir A (2012) Breaking male dominance by extraordinary means. In: Dahlerup D and Leyenaar M (eds) Breaking Male Dominance in Old Democracies. Oxford: Oxford Scholarship, 88-96.

Stjórnarráð Íslands (2009) Samstarfsyfirlýsing ríkisstjórnar: Samfylkingarinnar og Vinstrihreyfingarinnar - græns framboðs. 8 May. Available at: https://www.mbl. is/greinasafn/grein/1282359/ (accessed 22 February 2020).

Stjórnarráð Íslands (2019a) Forsætisráðherra undirritar samning við Samtökin '78. 2 February. Available at: https://www.stjornarradid.is/efst-a-baugi/frettir/ stok-frett/2019/02/07/Forsaetisradherra-undirritar-samning-vid-Samtokin-78 (accessed 19 April 2020).

Stjórnarráð Íslands (2019b) Forsaetisradherra undirritar samning vid Kvenrettindafelag Islands, June. Available at: https://www.stjornarradid.is/efst-abaugi/frettir/stok-frett/2020/02/18/Forsaetisradherra-undirritar-samning-vidKvenrettindafelag-Islands/ (accessed 19 April 2020).

Suchanow K (2020) How a harsh Polish abortion bill sparked women's strikes around the world. Open Democracy, 15 April. Available at: https://www.opendemocracy. net/en/5050/how-a-harsh-polish-abortion-bill-sparked-womens-strikes-aroundthe-world/ (accessed 17 April 2010).

Sunderland R (2009) After the crash, Iceland's women lead the rescue. Guardian, 21 February. Available at: https://www.theguardian.com/world/2009/feb/22/ iceland-women (accessed 18 April 2020).

Porvaldsdóttir P (2001) Af fegurðardísum, ástandskonum og fjallkonum. Lesið í táknmyndir hins kvenlega í íslensku menningarumhverfi. In: Agnarsdóttir A, Halldórsdóttir EH, Gísladóttir H, Hákonardóttir IH, Matthíasdóttir S and Porgrímsdóttir SK (eds) Kvennaslóðir. Rit til heiðurs Sigríði Th. Erlendsdóttur sagnfraðingi. Reykjavík: Kvennasögusafn Íslands, 493-506.

porvaldsdóttir PH (2011) The gender equal North: Icelandic images of femininity and masculinity. In: Ísleifsson SR and Chartier D (eds) Iceland and Images of the North. Québec/Reykjavík: Presses de l'Université du Québec, Collection Droit au Pôle/ReykjavíkurAkademían, 405-434.

Porvaldsdóttir PH (2014) Reimagining authoritative masculinity and the female slut: Snapshots from Reykjavík. In: Oddsdóttir EE, Sigurðsson AM and Svandal $\mathrm{S}$ (eds) Gender Equality in the Artic: Current Realities - Future Challenges. Reykjavík: Ministry for Foreign Affairs, 52-53. 


\section{Irma Erlingsdóttir}

Topping A and Redden M (2017) 'We are international, we are everywhere': Women united in global strike. Guardian, 7 March. Available at: https://www.theguardian. com/world/2017/mar/08/international-womens-day-political-global-strike (accessed 19 April 2020).

Tulinius K (2014) So what's this men's only UN Gender Conference I keep hearing about? Reykjavík Grapevine, 15 October. Available at: https:/grapevine.is/mag/ column-opinion/2014/10/15/so-whats-this-mens-only-un-gender-conference-ikeep-hearing-about/ (accessed 19 April 2020).

United Nations (2015) UN 'barbershop conference' aims to dispel stereotypes, promote gender equality. 15 January. Available at: https://news.un.org/en/ story/2015/01/488322 (accessed 19 April 2020).

Viktorin C, Gienow-Hecht JCE, Estner A and Will MK (2018) Beyond marketing and diplomacy: Exploring the historical origins of nation branding. In: Viktorin C, Gienow-Hecht JCE, Estner A and Will MK (eds) Nation Branding in Modern History. New York \& Oxford: Berghahn, 1-26.

Wittenberg-Cox A (2020) What do countries with the best coronavirus responses have in common? Women leaders. Forbes, 13 April. Available at: https://www. forbes.com/sites/avivahwittenbergcox/2020/04/13/what-do-countries-with-thebest-coronavirus-reponses-have-in-common-women-leaders/\#1e4c70103dec (accessed 19 April 2020).

Women Political Leaders (2014) Why Iceland is the world's global leader in gender equality? 24 March. Available at: https://www.womenpoliticalleaders.org/why-isiceland-the-world-s-global-leader-in-gender-equality/ (accessed 19 April 2020).

World Economic Forum (2020) Global Gender Gap Report 2020. Geneva: World Economic Forum. Available at: http://www3.weforum.org/docs/WEF_GGGR_2020. pdf (accessed 19 April 2020). 